\title{
Comparison of the Chromosomal Pattern of Primary Testicular Nonseminomas and Residual Mature Teratomas after Chemotherapy
}

\author{
Jannie van Echten, Wanda S. van der Vloedt, Mirjam van de Pol, \\ Anke Dam, Gerard J. te Meerman, Heimen Schraffordt Koops, \\ Dirk T. Sleijfer, J. Wolter Oosterhuis, and Bauke de Jong
}

\begin{abstract}
About 70 to $75 \%$ of patients with nonseminomatous testicular germ cell tumors (NSs) present with metastases. When these metastases are treated with chemotherapy, often residual mature teratoma (RMT) is left. RMT is composed of fully differentiated somatic tissue. Untreated metastases of NSs rarely consist exclusively of mature somatic tissue. Apparently, after chemotherapy treatment there is a shift towards higher degrees of differentiation. Investigating tumor progression and the mechanism(s) involved in therapy-related differentiation, we compared the cytogenetically abnormal karyotypes of a series of 70 NSs with those of 31 RMTs. In NSs and RMTs, the modal total chromosome number does not differ and is in the triploid range. Both the frequency and the average copy number of i(12p) are the same, and the pattern of chromosomal over-and underrepresentation and distribution of breakpoints do not differ significantly in these series. So, we found the chromosomal pattern of RMTs as abnormal as those of primary NSs. Based on cytogenetics, we found no indication that specific chromosomal alterations parallel metastasis and therapy-related differentiation of the metastases. The cytogenetic data suggest that both induction of differentiation of (selected) cells or selection of cells with capacity to differentiate are possible mechanisms for the therapy-related differentiation of RMTs. (C) Elsevier Science Inc., 1997
\end{abstract}

\section{INTRODUCTION}

Primary nonseminomatous testicular germ cell tumors (NSs) of adults are, in general, tumors with mixed histology. They can be composed of embryonal carcinoma (EC), yolk sac tumor (YS), choriocarcinoma (CH), immature teratoma (IT), and mature teratoma (MT) [1, 2]. A seminoma (SE) component may be present. Pure NSs, with one histological component, are rare [3]. At presentation, about 70 to $75 \%$ of patients with NSs have lymphatic and/or hematogenous metastases. However, NSs are highly curable solid tumors. The patients are treated by orchidectomy, in case of metastatic disease, followed by cisplatin-

From the Department of Medical Genetics (J. v. E., W. S. v. d. V., G. J. t. M., B. d. J.), Department of Pathology (A. D.), Department of Surgical Oncology (H. S. K.), and Department of Medical Oncology (D. T. S.), University of Groningen, Groningen; and Laboratory of Experimental Patho-Oncology (M. v. d. P., J. W. O.), Dr. Daniel den Hoed Cancer Center, Academic Hospital Rotterdam, Rotterdam, The Netherlands.

Address reprint requests to: Jannie van Echten, Ph. D., Department of Medical Genetics, University of Groningen, Ant. Deusinglaan 4, 9713 AW Groningen, The Netherlands.

Received August 12, 1996; accepted December 7, 1996. containing chemotherapy and additional surgical resection of residual mass [4].

From metastases of primary NSs treated with chemotherapy, often residual mature teratoma (RMT) is left. RMT is composed of fully differentiated, mature somatic tissue. As is the case in primary tumors, untreated metastases of primary NSs rarely consist exclusively of mature somatic tissue; they usually retain the histology of the primary tumor [5]. Apparently, after chemotherapy there is a shift towards higher degrees of differentiation. This effect of chemotherapy might be due to the induction of differentiation of malignant cells to more differentiated cells, to selective destruction of cells other than MT cells, or to selection of cells with an inherent capacity of (therapyrelated) differentiation. The mechanisms are not mutually exclusive [6].

Cytogenetic comparison of primary tumors and metastases may indicate chromosomal changes playing a role in tumor progression. Tumor progression is the result of clonal evolution of a tumor cell population, paralleled by karyotype evolution [7].

We compared the cytogenetically abnormal karyotypes of a series of $70 \mathrm{NSs}$ with those of 31 RMTs, in order to 
Table 1 Description of the modal composite karyotype and the modal chromosome number of 31 RMTs

\begin{tabular}{|c|c|c|}
\hline Case $^{a}$ & Description of modal composite karyotype & $\begin{array}{l}\text { Modal } \\
\text { number }\end{array}$ \\
\hline 1 & $61-79, X X,-Y,+1,+6,+8,+9,+10,+\mathrm{i}(12)(\mathrm{p} 10),+13,+17,-18,+21,+\operatorname{mar}[\mathrm{cp} 7]$ & 78 \\
\hline 2 & $42-60, \mathrm{XXY},-1,-2,-3,-4,-5,-9,-10,+\mathrm{i}(12)(\mathrm{p} 10) \times 2,-13,-14,-15,-18,-19,-20,+\operatorname{mar}[\mathrm{cp} 18]$ & 60 \\
\hline 3 & $62-63, X X Y,-8, i(12)(p 10),+i(12)(p 10) \times 2,-13,-14,-18,-20, \operatorname{del}(22)(q 12)[\mathrm{cp} 2]$ & 62,5 \\
\hline 4 & $\begin{array}{l}56-59, X X,-Y, \text { add }(1)(p 36), \operatorname{der}(2) t(2 ; 8)(q 32 ; q 23),-3,-4,-5,-9,-10,-11,+\mathrm{i}(12)(\mathrm{p} 10) \times 2,-13, \\
\quad \operatorname{dic}(13 ; 17)(\mathrm{p} 11 ; \mathrm{q} 22),-14,-15,-16,-17,-18,-19,-20, \operatorname{add}(22)(\mathrm{q} 11),+2 \operatorname{mar}[\mathrm{cp} 13]\end{array}$ & 58 \\
\hline 5 & $\begin{array}{l}59-62, \mathrm{XXY}, \operatorname{der}(1) \mathrm{t}(1 ; 3)(\mathrm{p} 32 ; \mathrm{p} 21),-2,-4,-5, \operatorname{der}(7) \mathrm{t}(5 ; 7)(\mathrm{q} 13 ; \mathrm{q} 22),-10,-11,+\mathrm{i}(12)(\mathrm{p} 10) \times 3 \\
-13,-14,-15, \operatorname{add}(17)(\mathrm{q} 25),-18,-19,+21,-22[\mathrm{cp} 3]\end{array}$ & 62 \\
\hline 6 & $\begin{array}{l}\text { 63-65,XXY,+del(1)(q41),-4,-5,+7,+8,add(9)(p13),-10,-10,-11, }+\mathrm{i}(12)(\mathrm{p} 10),-13,-14,-15, \\
\quad \operatorname{del}(16)(\mathrm{p} 13),-18,-19,+\operatorname{mar}[\mathrm{cp} 4]\end{array}$ & 63 \\
\hline 7 & $\begin{array}{l}49-54, X X,-Y, \operatorname{del}(1)(\mathrm{p} 34),-2,-3,-4,-5, \operatorname{der}(5) \mathrm{t}(3 ; 5)(\mathrm{q} 21 ; \mathrm{p} 15),-6,+\operatorname{add}(7)(\mathrm{q} 22),-9,-10, \text { add }(10) \\
\quad(\mathrm{q} 26),-11,-13,-14,-15,-16, \operatorname{del}(17)(\mathrm{p} 11),-18,-18,-19,-20,-21,-22,+\operatorname{der}(?) \mathrm{t}(? ; 18)(? ; \mathrm{q} 11) \\
\quad+\operatorname{mar}[\mathrm{cp} 14]\end{array}$ & 53 \\
\hline 8 & $\begin{array}{l}54-58, X X Y,-2,-3,-4,-9,-9,-10,-10,-11,+\mathrm{i}(12)(\mathrm{p} 10) \times 2,-13,-14,-15,-16,-18, \operatorname{del}(18)(\mathrm{p} 11) \\
-19,-21,-22,+\operatorname{der}(?) \mathrm{t}(? ; 9)(? ; \mathrm{q} 11),+2 \operatorname{mar}[\operatorname{cp} 6]\end{array}$ & 57 \\
\hline 9 & $\begin{array}{l}52-56, X X Y, \operatorname{del}(1)(\mathrm{p} 3 ? 5),-2,-3,-4,-5,+6,-9,-10,-11,+\operatorname{add}(12)(\mathrm{p} 13),+\mathrm{i}(12)(\mathrm{p} 10) \times 2,-13,-14, \\
\quad-15,-16,-18,-19,-20,-21,-22[\mathrm{cp} 9]\end{array}$ & 52 \\
\hline 10 & $\begin{array}{l}56-58, \mathrm{XXY}, \text { add(1)(p11),add(1)(p34), }-2,-3,-4,-5,-8, \operatorname{del}(8)(\mathrm{p} 22),-9,-10,-11,+\mathrm{i}(12)(\mathrm{p} 10) \times 2 \\
-13,-14,-14,-15,-16,-18,-19,-20,+21,-22,+2 \operatorname{mar}[\mathrm{cp} 9]\end{array}$ & 57 \\
\hline 11 & $\begin{array}{l}78-88, \mathrm{XXY},+1,+2,+3,+3,+\operatorname{add}(5)(\mathrm{q} 31),-6, \operatorname{add}(7)(\mathrm{p} 11), \operatorname{der}(7) \mathrm{t}(7 ; 7)(\mathrm{p} 22 ; \mathrm{q} 11),+\operatorname{inv}(7)(\mathrm{p} 15 \mathrm{p} 22) \\
\quad+8,+9,+\operatorname{del}(10)(\mathrm{p} 13), \operatorname{add}(11)(\mathrm{q} 25),+12,+\operatorname{del}(12)(\mathrm{q} 21 \mathrm{q} 24),+\mathrm{i}(12)(\mathrm{p} 10) \times 3,+13,+14,+17,+20 \\
\quad+21,-22,-22, \mathrm{i}(22)(\mathrm{q} 10),+\operatorname{der}(?) \mathrm{t}(? ; 7)(? ; \mathrm{p} 10),+\operatorname{mar}[\operatorname{cp} 18]\end{array}$ & 85 \\
\hline 12 & $\begin{array}{l}57-66, \mathrm{XXY},+\mathrm{Y},-1,-4,-5,-6,+7,+7,+\operatorname{del}(7)(\mathrm{q} 31),-8,-10,-11,+\mathrm{i}(12)(\mathrm{p} 10),-13,-14,-17,-18 \\
\quad-19,+21,-22,+\operatorname{der}(?) \mathrm{t}(? ; 5)(? ; \mathrm{q} 13),+\operatorname{mar}[\mathrm{cp} 9]\end{array}$ & 62 \\
\hline 13 & $\begin{array}{l}55-57, \mathrm{XY},-\mathrm{X}, \text { add }(1)(\mathrm{p} 36),-4,-6,-9,-10,-11,+\mathrm{i}(12)(\mathrm{p} 10) \times 2,-13,-14,-15,-18,-19,-20 \\
\quad-21,-22[\mathrm{cp} 9]\end{array}$ & 57 \\
\hline 14 & $\begin{array}{l}62-66, X Y,+Y, \operatorname{del}(X)(p 21)+\operatorname{add}(1)(p 36), \operatorname{der}(2) \mathrm{t}(1 ; 2)(\mathrm{q} 21 ; \mathrm{q} 37),-4,+7,-9,-10,-11,+\mathrm{i}(12)(\mathrm{p} 10) \times 2, \\
\text { add(13)(p11),-14,-18,-19,-20,-22[cp9] }\end{array}$ & 64 \\
\hline 15 & $\begin{array}{l}56-59, X X Y,+X, \operatorname{dic}(1 ; 20) \operatorname{del}(1)(20 \mathrm{qter} \rightarrow 20 \mathrm{p} 13:: 1 \mathrm{q} 44 \rightarrow 1 \mathrm{q} 12:: 1 \mathrm{q} 21 \rightarrow 1 \mathrm{p} 34),-2,-3,-4, \operatorname{del}(4)(\mathrm{p} 15), \\
\quad-5, \operatorname{add}(7)(\mathrm{q} 11),-9,-10,-11, \operatorname{add}(11)(\mathrm{q} 23), \operatorname{add}(12)(\mathrm{q} 24),+\mathrm{i}(12)(\mathrm{p} 10) \times 2,-13,-14,-15,-16,-18, \\
-19,-20,-21, \operatorname{der}(22) \mathrm{t}(7 ; 22)(\mathrm{q} 11 ; \mathrm{q} 13)[\mathrm{cp} 7]\end{array}$ & 58 \\
\hline 16 & $\begin{array}{l}57-62, X X Y,+Y,+\operatorname{der}(1) t(1 ; 6)(\mathrm{p} 34 ; \mathrm{p} 21),-2,-4,-9,-10,-11,+\mathrm{i}(12)(\mathrm{p} 10),-13,-14,-15,-18,-19, \\
\operatorname{add}(20)(\mathrm{p} 13),+\operatorname{add}(20)(\mathrm{p} 13),-22[\mathrm{cp} 9]\end{array}$ & 60 \\
\hline 17 & 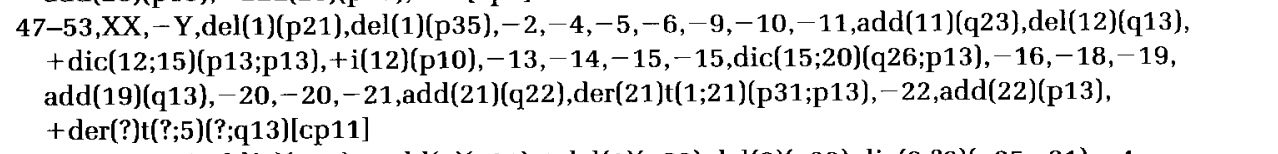 & 52 \\
\hline 18 & $\begin{array}{l}54-63, X X,-Y, \operatorname{add}(1)(p 32),+\operatorname{add}(1)(\mathrm{q} 21),+\operatorname{del}(1)(\mathrm{p} 22), \operatorname{del}(2)(\mathrm{q} 33), \operatorname{dic}(2 ; ? 6)(\mathrm{p} 25 ; \mathrm{q} 21),-4 \\
\quad+\operatorname{del}(8)(\mathrm{p} 12),+\operatorname{der}(8) \mathrm{t}(1 ; 8)(\mathrm{p} 22 ; \mathrm{p} 11),-9,-10,+\mathrm{i}(12)(\mathrm{p} 10) \times 2,-13,-15,-16,-18,-18 \\
\quad \mathrm{i}(18)(\mathrm{q} 10),-19,-21,-22,+2 \operatorname{mar}[\mathrm{cp} 10]\end{array}$ & 61 \\
\hline 19 & $\begin{array}{l}\text { 61-66,XXY,add(1)(p36) } \times 2,+\operatorname{del}(1)(\mathrm{q} 11),+\operatorname{del}(2)(\mathrm{p} 24),-4,-5,+\operatorname{add}(6)(\mathrm{p} 22),+8,-9,-10 \\
\quad+\mathrm{i}(12)(\mathrm{p} 10) \times 2,-13, \operatorname{dic}(13 ; 13)(\mathrm{p} 12 ; \mathrm{p} 12),-14,-15, \operatorname{add}(15)(\mathrm{p} 12),-16,-18,-19, \operatorname{del}(20) \\
(\mathrm{p} 12),-22,+\operatorname{mar}[\mathrm{cp} 10]\end{array}$ & 64 \\
\hline 20 & $\begin{array}{l}60-65, X X Y,+Y, \operatorname{del}(1)(p 34), \operatorname{der}(1) \mathrm{t}(1 ; 5)(\mathrm{q} 23 ; \mathrm{q} 13),-4,-5,+\operatorname{der}(6) \mathrm{t}(6 ; 7)(\mathrm{q} 11 ; \mathrm{p} 11),+\operatorname{der}(8) \mathrm{t}(8 ; 9) \\
(\mathrm{p} 21 ; \mathrm{q} 11),-9,-10,-11,+\mathrm{i}(12)(\mathrm{p} 10) \times 2,-13,-14,-15,-16,-18,-19,+20,+21,-22,+\operatorname{mar}[\mathrm{cp} 11]\end{array}$ & 63 \\
\hline
\end{tabular}

study chromosomal changes playing a role in tumor progression (e.g., metastasis) and/or the mechanism(s) involved in therapy-related differentiation. A distinction between both events cannot be made because, due to the application of standardized clinical protocols, we are not able to investigate the chromosomal pattern of untreated metastases of NSs.

\section{MATERIALS AND METHODS}

A cytogenetic comparison of 70 NSs with 31 RMTs was carried out. Culturing and harvesting of the tumors was performed using standard cytogenetic techniques [8, 9]. For each tumor, a modal composite karyotype description was made according to the ISCN 1995 [10]. However, all karyotype descriptions are based on the triploid level, since this makes over- and underrepresentation of specific chromosomes-an important feature of testicular germ cell tumors [9, 11]-better visible and comparable. Only NSs and RMTs with an abnormal karyotype are included in this study, because NSs and RMTs show a consistently high DNA index (DI) [12-16].

For each tumor and chromosome, the average number of short and long arms was determined. Parts of chromosomal arms involved in structural abnormalities were reg- 
Table 1 Continued

\begin{tabular}{|c|c|c|}
\hline Case & Description of modal composite karyotype & $\begin{array}{l}\text { Modal } \\
\text { number }\end{array}$ \\
\hline 21 & $\begin{array}{l}\text { 56-60,XXY,der(1)t(1;4)(p11;q11),-2,add(2)(p25),-4,-5,-6,-6,dup(7)(q11.2q21), +8,-9,-10, } \\
\quad-11, \operatorname{add}(11)(\mathrm{q} 24),-13,-16,-17,-18,+\operatorname{mar}[\mathrm{cp} 6]\end{array}$ & 59 \\
\hline 22 & $\begin{array}{l}57-59, X Y,-X, \text { add(1)(p36), }-2, \operatorname{del}(3)(\mathrm{p} 21),-4,-7,+\mathrm{i}(8)(\mathrm{q} 10),-9,-10,-11,+\mathrm{i}(12)(\mathrm{p} 10),-13,-13, \\
\quad-14,-15, \operatorname{del}(16)(\mathrm{p} 13), \operatorname{der}(16) \mathrm{t}(7 ; 16)(\mathrm{q} 11 ; \mathrm{q} 24),-18,-19,-20,+\operatorname{der}(?) \mathrm{t}(? ; 13)(? ; \mathrm{q} 12)[\mathrm{cp} 7]\end{array}$ & 58 \\
\hline 23 & $\begin{array}{l}\text { 54-64,XXY,del(1)(p11),-4,-5,dic(5;5)(p15.3;p15.3), }+\operatorname{der}(7) \mathrm{t}(7 ; 7)(\mathrm{q} 31 ; \mathrm{p} 11.2),-11,+\mathrm{i}(12) \\
(\mathrm{p} 10) \times 2,-14, \text { add(14)(p13),-15,-16,-18,-19,add(20)(p12),+21,-22[cp10] }\end{array}$ & 61 \\
\hline 24 & $\begin{array}{l}47-59, X X Y,+Y, \text { add(1)(p36), der(2)t(2;9)(p23;q11), }-4,-5,-8,-9,-9,-10,-11,-13, \operatorname{add}(14)(\mathrm{p} 13), \\
\quad-15, \operatorname{add}(16)(\mathrm{q} 22),-18,-19,-20,+\operatorname{mar}[\mathrm{cp} 10]\end{array}$ & 58 \\
\hline 25 & $\begin{array}{l}57-64, X X Y,+X, \text { add }(1)(p 36),-2,-4,-5,+\operatorname{add}(7)(q 21), \operatorname{der}(8) \mathrm{t}(8 ; 21)(\mathrm{p} 11 ; \mathrm{q} 21),-9,-10,-11 \\
\quad+\mathrm{i}(12)(\mathrm{p} 10) \times 2,-13,-14,-15,-16,-18,-19,+21,-22,+2 \operatorname{mar}[\mathrm{cp} 10]\end{array}$ & 60 \\
\hline 26 & $\begin{array}{l}47-58, X X Y, \operatorname{add}(1)(\mathrm{p} 36),-2, \operatorname{del}(3)(\mathrm{p} 23),-4,-5,-6,+\operatorname{add}(7)(\mathrm{q} 22), \operatorname{add}(8)(\mathrm{p} 23),-9,-10, \operatorname{add}(10) \\
(\mathrm{q} 26),-11,+\operatorname{add}(12)(\mathrm{p} 13) \times 2,-13,-14,-15,-16, \operatorname{del}(17)(\mathrm{p} 11),-18,-20, \operatorname{der}(20) t(6 ; 20) \\
\text { (p11;p13),-22[cp4] }\end{array}$ & 56 \\
\hline 27 & $\begin{array}{l}\text { 57-62,XXY,add(1)(p13),add(2)(q11), }-3, \operatorname{add}(3)(\mathrm{q} 26),-4, \operatorname{add}(5)(\mathrm{q} 35), \operatorname{add}(7)(\mathrm{p} 22), \operatorname{der}(7) \\
\mathrm{t}(7 ; 7 ; 18)(7 \mathrm{qter} \rightarrow 7 \mathrm{p} 22:: 7 \mathrm{q} 11 \rightarrow 7 \mathrm{q} 34:: 18 \mathrm{q} 11 \rightarrow 18 \mathrm{qter}),+\operatorname{add}(8)(\mathrm{p} 23),-9,-10,-13, \operatorname{add}(14) \\
(\mathrm{q} 32),-15,-18,-18, \operatorname{der}(18) \mathrm{t}(2 ; 18)(\mathrm{q} 14 ; \mathrm{p} 11), \operatorname{add}(19)(\mathrm{q} 12),-20,-22,+3 \operatorname{mar}[\mathrm{cp} 10]\end{array}$ & 58 \\
\hline 28 & $\begin{array}{l}\text { 50-61,XXY,add(1)(q32),add(1)(p36),-2,-4,-5,-6,+8,-9,-10,-11,+i(12)(p10),-13,-15, } \\
\quad-16, \mathrm{i}(17)(\mathrm{q} 10),-18,-19,-19, \operatorname{add}(19)(\mathrm{q} 13),-20,+\operatorname{der}(?) \mathrm{t}(? ; 12)(? ; \mathrm{p} 11),+\operatorname{mar}[\mathrm{cp} 10]\end{array}$ & 58 \\
\hline 29 & $\begin{array}{l}56-62, X X Y,+Y, \operatorname{add}(1)(\mathrm{p} 11), \operatorname{add}(2)(\mathrm{q} 13),-3,-4,-5,-6, \operatorname{add}(6)(\mathrm{q} 16),+\operatorname{add}(7)(\mathrm{q} 32),-9, \operatorname{der}(9) \\
\mathrm{t}(6 ; 9)(\mathrm{q} 11 ; \mathrm{q} 21), \operatorname{der}(10) \mathrm{t}(9 ; 10)(\mathrm{q} 21 ; \mathrm{q} 21)-11,+\mathrm{i}(12)(\mathrm{p} 10) \times 2,-13,-15,-17,-18,-19, \operatorname{add}(19) \\
(\mathrm{p} 13),-22,+2 \operatorname{mar}[\mathrm{cp} 10]\end{array}$ & 60 \\
\hline 30 & $\begin{array}{l}56-82, \mathrm{XXY}, \operatorname{add}(1)(\mathrm{p} 34), \operatorname{add}(2)(\mathrm{p} 13),-4,-5,-9,-10,-11,+\mathrm{i}(12)(\mathrm{p} 10) \times 2,-13,-14,-15,-18, \\
\quad-19,-20,-22,+2 \operatorname{mar}[10]\end{array}$ & 59 \\
\hline 31 & $\begin{array}{l}59-62, X X Y, \operatorname{del}(1)(\mathrm{p} 35),-2, \operatorname{add}(3)(\mathrm{p} 12),-4,-5,+\operatorname{del}(8)(\mathrm{p} 11),-9,-10, \operatorname{add}(10)(\mathrm{q} 22),-11,-13, \\
\quad-14,-15,-18,-19, \operatorname{der}(20) \mathrm{t}(12 ; 20)(\mathrm{p} 11 ; \mathrm{p} 11),+21,-22,+2 \operatorname{mar}[\mathrm{cp} 10]\end{array}$ & 61 \\
\hline
\end{tabular}

${ }^{\sigma}$ Cases 1 to 13 have been described previously (Castedo et al. [17])

istered as whole arms if they represented $50 \%$ or more of the total arm length. The modal number of short and long arms divided by two revealed the average modal number of chromosomes. The average number of sex chromosomes for each tumor was multiplied by two to allow comparison with the autosomes [9, 11].

Statistical analysis and comparison of the cytogenetic data of the NSs and RMTs was performed using the Mann-

Table 2 Histological components of 70 NSs

\begin{tabular}{|c|c|c|c|c|c|c|c|}
\hline Case & Histology & Case & Histology & Case & Histology & Case & Histology \\
\hline 1 & YS;CH;EC;MT & 21 & EC;MT & 41 & YS;CH;EC;IT;MT & 61 & YS;IT;MT \\
\hline 2 & EC;IT;MT & 22 & YS;EC;IT;MT;SE & 42 & EC;MT & 62 & YS;MT \\
\hline 3 & YS;EC & 23 & YS;CH;EC;MT & 43 & YS;EC;MT & 63 & YS;EC;IT;MT \\
\hline 4 & MT & 24 & YS;EC;IT;MT;SE & 44 & YS;EC;IT;MT & 64 & MT \\
\hline 5 & YS;EC;IT;MT;SE & 25 & EC;IT;MT & 45 & IT;MT & 65 & YS;MT \\
\hline 6 & YS;EC;MT & 26 & EC;IT;MT & 46 & YS;EC & 66 & YS;IT;MT \\
\hline 7 & YS;EC;IT;MT & 27 & YS;EC;IT;MT & 47 & MT & 67 & EC;IT \\
\hline 8 & MT & 28 & YS;IT;MT;SE & 48 & YS;EC & 68 & YS;EC;IT;MT \\
\hline 9 & $\mathrm{EC}$ & 29 & YS;CH;EG;IT;MT & 49 & YS;CH;EC;IT;MT;SE & 69 & EC;MT \\
\hline 10 & EC;MT & 30 & YS;CH;EC;IT;MT & 50 & EC & 70 & YS;EC;IT;MT \\
\hline 11 & EC;MT;SE & 31 & YS;EC;MT;SE & 51 & EC;IT;MT & & \\
\hline 12 & EC;SE & 32 & YS;EC;IT;MT & 52 & $\mathrm{CH} ; \mathrm{EC} ; \mathrm{MT}$ & & \\
\hline 13 & YS;EC;IT;MT & 33 & YS;EC & 53 & EC;IT;MT & & \\
\hline 14 & YS;EC;IT;MT & 34 & YS;EC;IT;MT;SE & 54 & YS;EC;IT;MT & & \\
\hline 15 & YS;CH;EC;IT;MT & 35 & EC;IT;MT;SE & 55 & EC & & \\
\hline 16 & MT;SE & 36 & EC;IT;MT & 56 & YS;SE & & \\
\hline 17 & EC;IT;MT & 37 & YS;EC;MT & 57 & $\mathrm{CH} ; \mathrm{EC} ; \mathrm{MT} ; \mathrm{SE}$ & & \\
\hline 18 & YS;EC;IT;MT & 38 & YS;IT & 58 & MT;SE & & \\
\hline 19 & YS;EC & 39 & YS;EC;IT;MT;SE & 59 & EC;MT & & \\
\hline 20 & YS & 40 & YS;EC;IT;MT & 60 & $\mathrm{EC} ; \mathrm{SE}$ & & \\
\hline
\end{tabular}

Abbreviations: YS, yolk sac tumor; CH, choriocarcinoma; EC, embryonal carcinoma; MT, mature teratoma; IT, immature teratoma; $\mathrm{SE}$, seminoma. 
Whitney U or chi-square test with Bonferroni's correction for multiple testing, when necessary.

\section{RESULTS}

\section{Karyotypes}

The modal composite karyotypes and the modal chromosome numbers for the 31 chromosomally abnormal cases of RMTs are given in Table 1. Cases 1 to 13 have been published [17], as well as the 70 chromosomally abnormal NSs [9]. Table 2 shows the histological components of the 70 NSs. From 10 patients, both the primary NS and the RMT were analyzed (cases of NS and RMT respectively: 7 and 11,13 and 14,14 and 15, 16 and 16,17 and 17, 24 and 20,32 and 26,45 and 27,46 and 30,49 and 29 ).

\section{Statistical Analysis and Comparison of NSs and RMTs}

The Mann-Whitney U test showed no significant difference between the modal total chromosome number in NSs (average, 65.0; standard deviation [SD], 13.5; $\mathrm{n}=70$ ) and RMTs (average, 60.5; SD, 6.5; $n=31)(p>0.053)$. Figure 1 clearly shows that the average number of copies of the different chromosomes is highly similar in the series of NSs and RMTs (Spearman rank correlation: 0.918, $p<0.001$ ). In RMTs and NSs, a similar pattern of overrepresentation (e.g., chromosomes 7, 8, 12, 21, and X) and underrepresentation (e.g., 11, 13, 18, and Y) is present. Additionally, Figure 2 shows this similar pattern of over- and underrepresentation of (parts of) chromosomes (Fig. 2A has been published before [9]). Chromosome arm 12p was clearly overrepresented, mainly due to i(12p), in NSs and RMTs. No significant difference in number of copies of the different chromosomes was observed when groups of NSs without a teratoma component $(n=12)$, NSs with a teratoma component $(\mathrm{n}=58)$, and RMTs $(\mathrm{n}=31)$ were compared $(p>0.05)$.

Both the frequency of $\mathrm{i}(12 \mathrm{p})$ ( $83 \%$ in NSs and $81 \%$ in the RMTs) as well as the average copy number of $i(12 p)$ (1.7; SD, 1.0 in the NSs and 1.5; SD, 0.9 in the RMTs) did not differ significantly between NSs and RMTs ( $p>0.05$ ).

Figure 3 shows the number and location of breakpoints in each chromosome in the 70 NSs and 31 RMTs. The distribution of breakpoints in both groups does not differ significantly $(p>0.001)$. In both the NSs and RMTs, a

Figure 1 Average modal number per chromosome in a group of 70 NSs (dark line) and 31 RMTs (thin line) (see Materials and Methods for the calculation of modal numbers). The average number of the sex chromosomes for each case was multiplied by two to allow comparison with the autosomes. In addition, the average number of short and long arms of chromosome 12 is indicated separately (circles $=12 p$ and $12 q$ NS; rectangles $=12 p$ and 12q RMT).

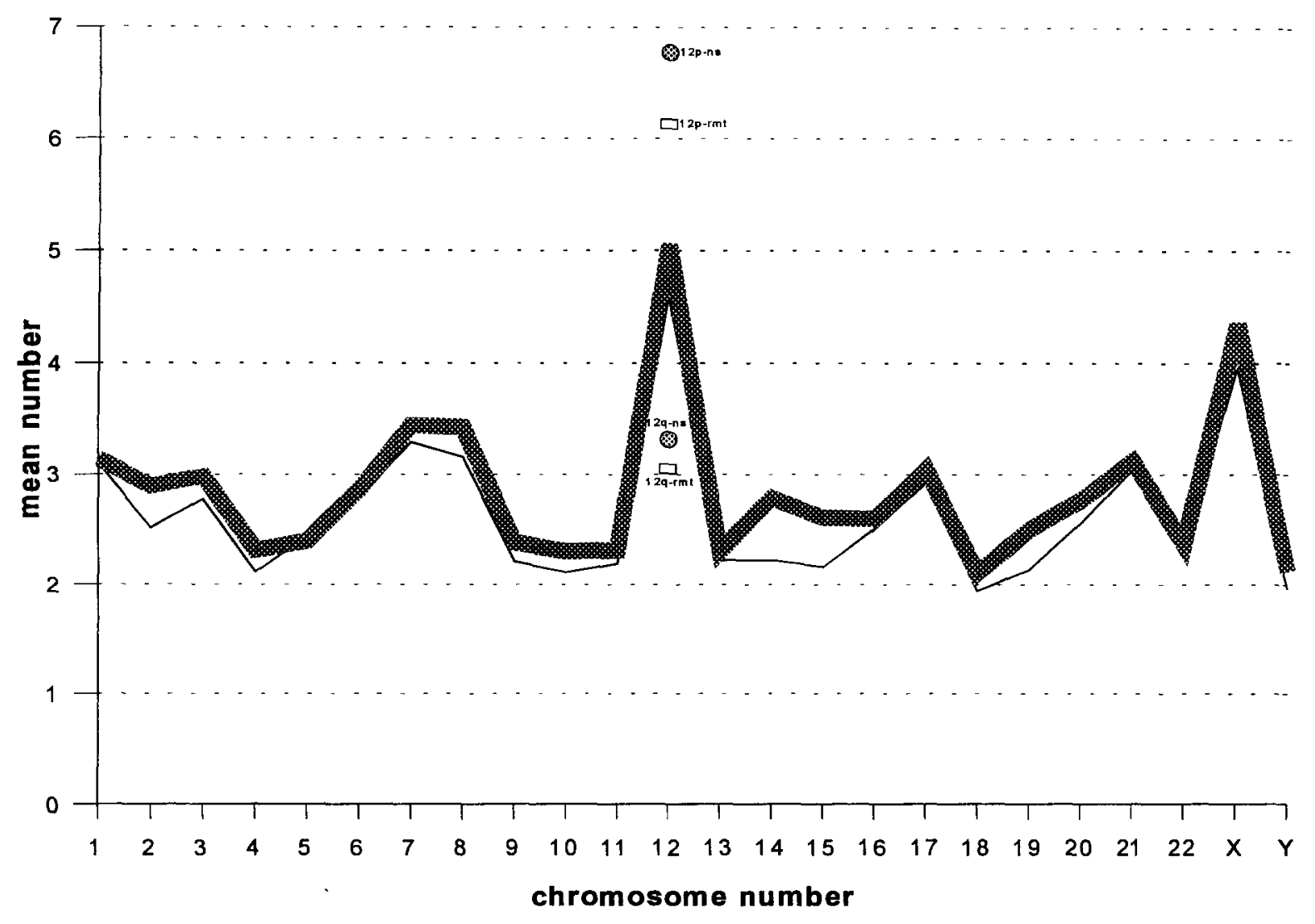


clustering of breakpoints was found in chromosome 1 and $12(p<0.001)$; for chromosome 12 , mainly due to $\mathrm{i}(12 \mathrm{p})$.

\section{DISCUSSION}

Cytogenetic comparison of primary tumors and metastases may indicate chromosomal changes playing a role in tumor progression. Tumor progression is the result of clonal evolution of a tumor cell population and is paralleled by karyotype evolution [7]. Due to clonal evolution and selection, malignant tumors are genetically heterogeneous and contain multiple subpopulations of cancer cells. Only certain subpopulations of tumor cells have the capacity to form metastatic lesions [18]. Due to the application of standardized clinical protocols, we are not able to investigate the chromosomal pattern of untreated metastases of NSs. It is only possible to study residual lesions following chemotherapy-often residual mature teratoma (RMT). These RMT lesions are composed of fully differentiated tissue [6]. This higher degree of differentiation after chemotherapy treatment might be due to direct induction of differentiation of malignant cells to fully differentiated cells, to selective destruction of cells other than MT cells, or to selection of cells with an inherent capacity of spontaneous differentiation or capacity of therapy-related differentiation $[6,17,19-21]$.

A cytogenetic comparison between NSs and RMTs may shed light on the chromosomal changes playing a role in tumor progression and on the mechanism(s) of therapyrelated differentiation, although a distinction between these events cannot be made.

The present study, a cytogenetic comparison of a series of 70 NSs and 31 RMTs, revealed no significant chromosomal differences between the two groups. This may be explained in different ways.

First, by clonal dominance. This means that during progression a primary tumor gradually becomes overgrown by the progeny of a metastatic clone. This primary tumor consists almost exclusively of cells of this dominant metastatic clone and is biologically equivalent to the metastasis [22]. The cells of the primary tumor and the metastasis will show identical or very similar karyotypes. Under the influence of therapy, the metastatic cells differentiate irrespective of their highly abnormal karyotype.

Second, the observed chromosomal similarities between NSs and RMTs might be due to in vitro selection during culture. The histology of primary NSs in general is heterogeneous. RMT is most often found when the primary tumor contains MT [6]. It might be that this MT component populates the RMT and is selected in the culture of the primary NS.

Third, one would not expect to find chromosomal differences between primary NSs and RMTs, when metastasis is not caused or accompanied by visible chromosomal alterations and when RMTs are the result of therapyrelated induction of differentiation of cells, irrespective of their chromosomal pattern [17]. If RMTs are the result of selection or of differentiation of selected cells with an abnormal chromosomal pattern, but with a proper bal- anced chromosomal constitution allowing differentiation, one might only expect specific chromosomal differences between the primary NSs and RMTs [17] when different directions or degrees of differentiation are brought about by differences in chromosomal pattern. However, in an NS and a metastatic NS, respectively, we observed comparable karyotypes in the different pure histological components, which were karyotyped separately [23, 24]. Furthermore, in our series of NSs with pure histology [9], although small, we have no indications that the different histological components have different specific chromosomal constitutions. These data suggest that, in NSs, differences in direction of differentiation are not accompanied by gross chromosomal changes. Therefore, when RMTs are the result of differentiation of selected cells, and when metastasizing and differentiation are not paralled by visible chromosomal alterations, one also may observe common karyotypes between the primary NSs and RMTs.

So, based on cytogenetics, both induction of differentiation or selection of cells with capacity to differentiate are possible mechanisms for the therapy-related differentiation of RMTs. In two different studies, Oosterhuis et al. [6, 12,25 ] found their results being compatible with selection as the mechanism of therapy-related differentiation.

In a previous cytogenetic comparison of a series of 14 NSs and 13 RMTs, we observed some differences between NSs and RMTs (e.g., smaller over- and underrepresentation of specific chromosomes and less i(12p)-copies and breakpoints in RMTs than in NSs). These findings lead us to conclude that RMTs are the result of selection of clones with a less abnormal karyotype and possibly the right balance of genes allowing differentiation [17]. In our present, much larger series of NSs and RMTs, we found no evidence for the selection of clones with a less abnormal karyotype. However, selection of cells is still a possible mechanism.

Murty et al. [26] found that well-differentiated teratomas exhibited a significantly higher level of allelic loss compared to the less differentiated embryonal carcinomas. Their results led them to suggest that nonrandom loss or inactivation of certain genes may be associated with tumor development and that loss or inactivation of other genes may be associated with somatic differentiation. Cytogenetically, we did not find a significant difference in loss of specific chromosomal parts in RMTs compared to primary NSs with different histologies.

In conclusion, the two groups of primary NSs and RMTs showed comparable chromosomal patterns. We found no cytogenetic evidence for specific chromosomal alterations to be related to the progression of primary NSs to metastasis and/or therapy-related differentiation. Both induction of differentiation of (selected) cells or selection of cells with capacity to differentiate are possible mechanisms for the therapy-related differentiation of RMTs. Genetic changes not detectable at the chromosomal level or epigenetic factors may play a role in the tumor progression and/or in the therapy-related differentiation of these tumors. It might be that most chromosomal changes related with tumor progression in NSs take place very early during tumor development, probably when the non-inva- 

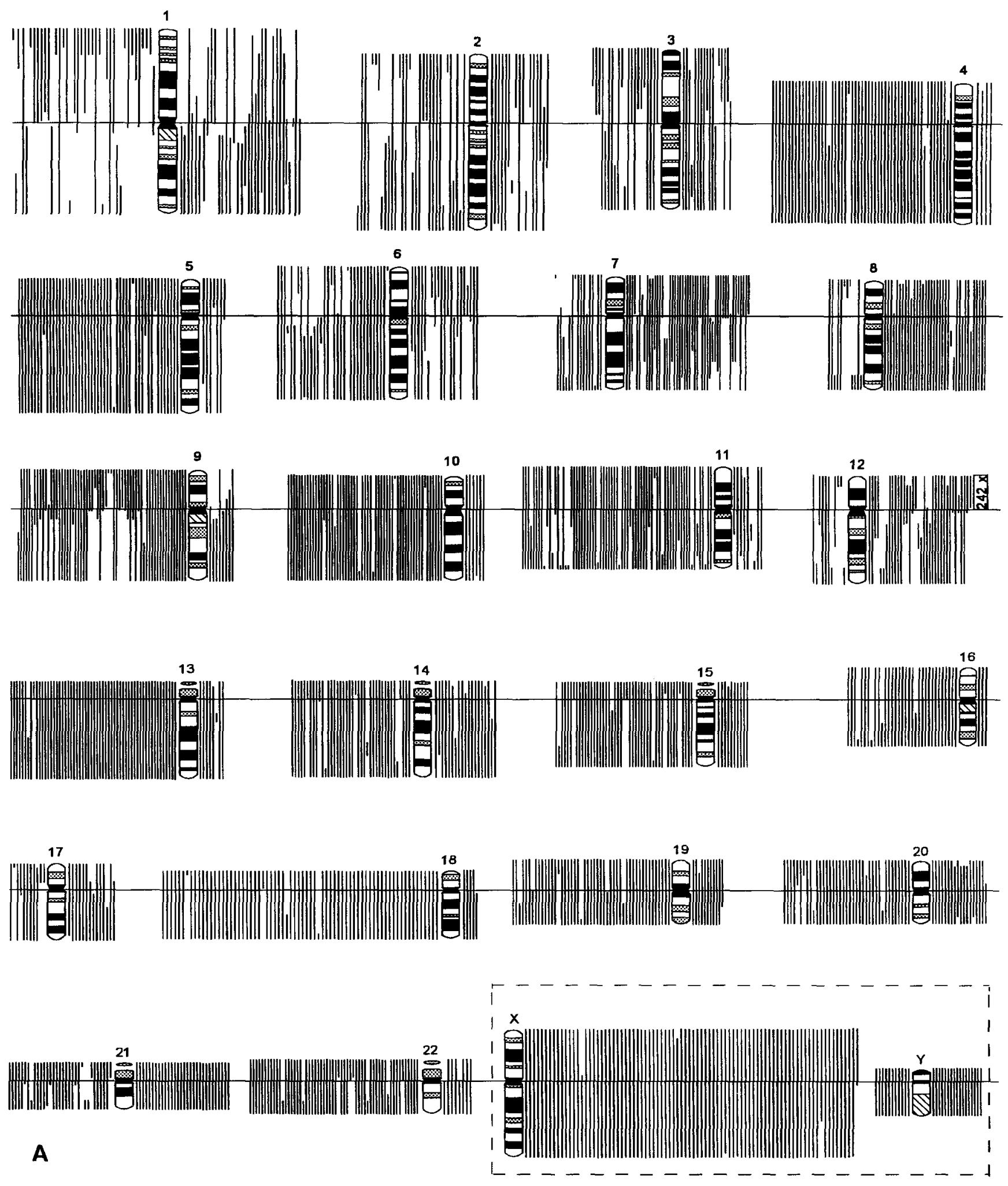

Figure 2 Over- and underrepresentation of (parts of) chromosomes in 70 NSs (A) [9] and 31 RMTs (B). The autosomes are calculated on the basis of a triploid DNA content (expected number is three), while the sex chromosomes are calculated on the basis of a diploid DNA content (expected number is one). The relative overrepresented regions are indicated per tumor on the right side of the chromosomes, while the underrepresented regions are indicated on the left side. The copy number of $12 p$, due to i(12p), is indicated inside a rectangle. 

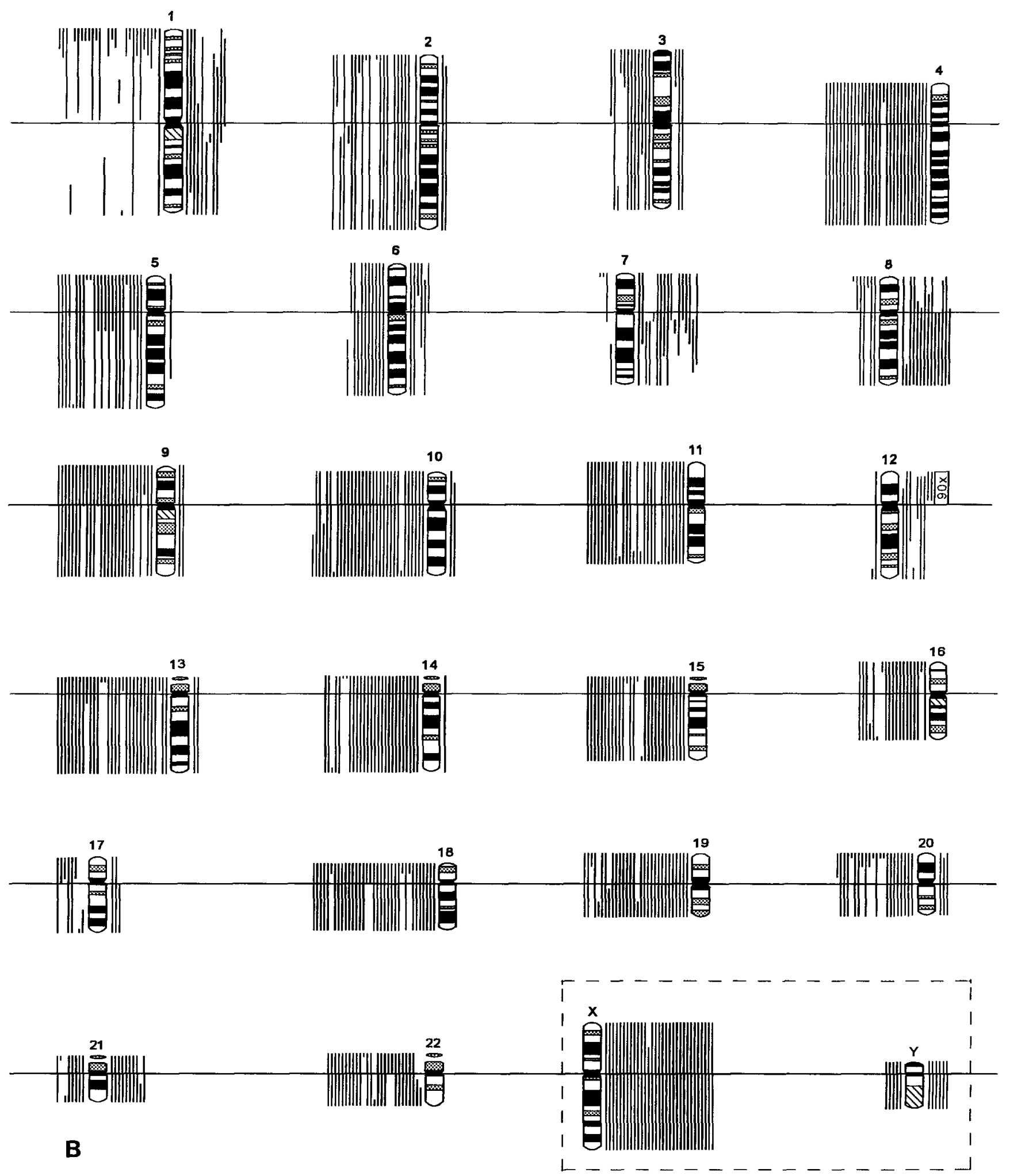

Figure 2 Continued 

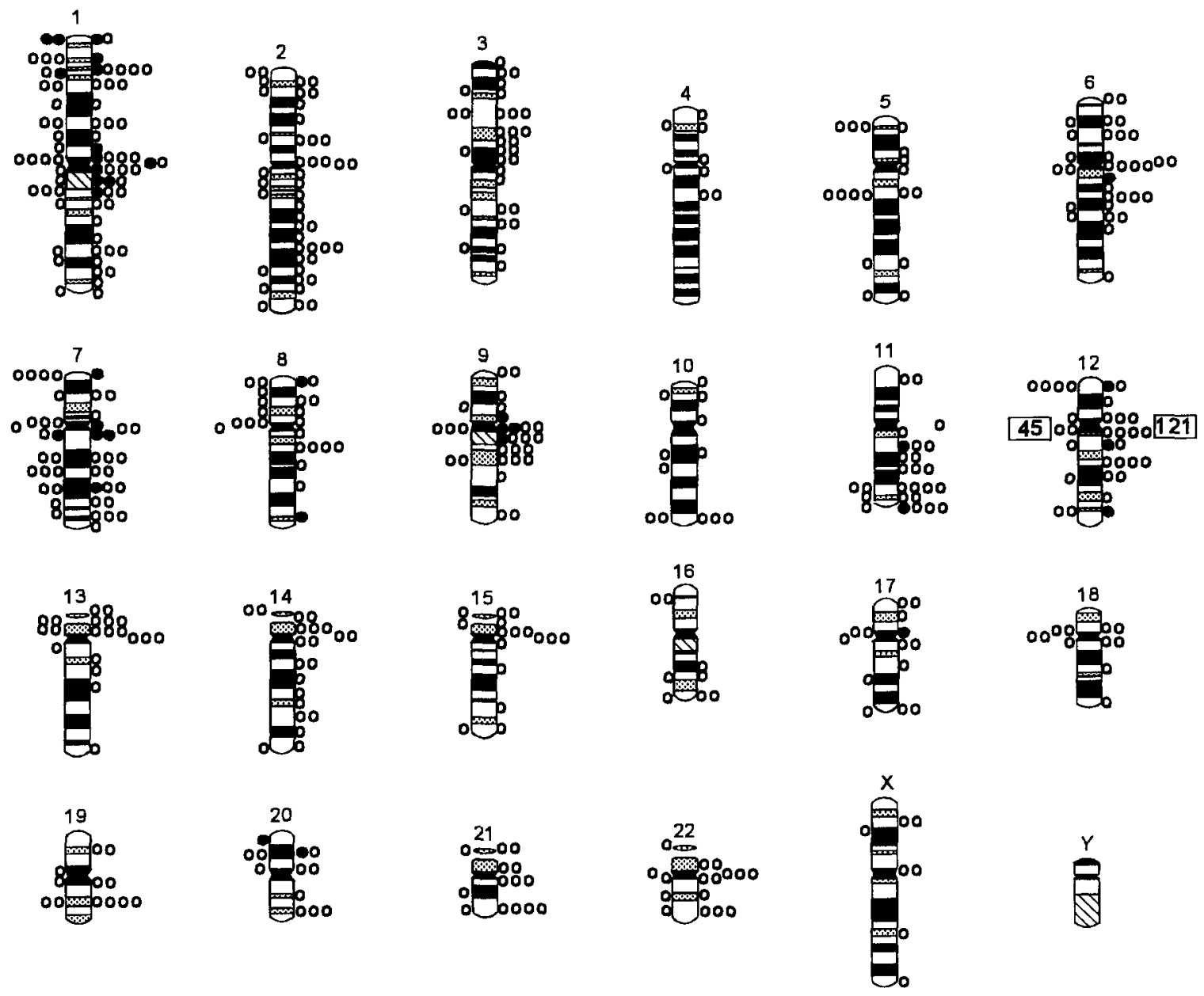

Figure 3 Chromosomal distribution of breakpoints in 70 NSs (right side of each chromosome) and 31 RMTs (left side of each chromosome). $O=1$ breakpoint; $=5$ breakpoints. The number of breakpoints in $12 p 10$ is indicated inside a rectangle.

sive precursor, carcinoma in situ, develops into invasive tumor.

\section{REFERENCES}

1. Mostofi FK, Sesterhenn IA, Davis CJ (1987): Immunopathology of germ cell tumors of the testis. Semin Diagn Path 4:320-341.

2. Damjanov I (1991): Pathobiology of human germ cell neoplasia. Recent Results Cancer Res 123:1-19.

3. Ulbright TM (1993): Germ cell neoplasms of the testis. Am J Surg Pathol 17:1075-1091.

4. Einhorn LH (1990): Treatment of testicular cancer: a new and improved model. J Clin Oncol 8:1777-1781.

5. Oosterhuis JW (1983): The metastasis of human teratomas. In: The Human Teratomas. I Damjanov, B Knowles, D Solter, eds. The Humana Press, Clifton, New Jersey, pp. 137-171.

6. Oosterhuis JW, Suurmeyer AJH, Sleijfer DT, Schraffordt Koops H, Oldhoff J, Fleuren G (1983): Effects of multipledrug chemotherapy (Cis-diammine-dichloroplatinum, bleomycin, and vinblastine) on the maturation of retroperitoneal lymph node metastases of nonseminomatous germ cell tumors of the testis. No evidence for de novo induction of differentiation. Cancer 51:408-416.

7. Nowell PC (1986): Mechanisms of tumor progression. Cancer Res 46:2203-2207.

8. Castedo SMMJ, de Jong B, Oosterhuis JW, Seruca R, Idenburg VJS, Dam A, te Meerman GJ, Schraffordt Koops H, Sleijfer DT (1989): Chromosomal changes in human primary testicular nonseminomatous germ cell tumors. Cancer Res 49:56965701.

9. van Echten J, Oosterhuis JW, Looijenga LHJ, van de Pol M, Wiersema J, te Meerman GJ, Schraffordt Koops H, Sleijfer DT, de Jong $B$ (1995): No recurrent structural abnormalities apart from $i(12 p)$ in primary germ cell tumors of the adult testis. Genes Chromosom Cancer 14:133-144.

10. ISCN (1995): An International System for Human Cytogenetic Nomenclature. F Mitelman, ed. S Karger, Basel.

11. de Jong B, Oosterhuis JW, Castedo SMMJ, Vos AM, te Meerman GJ (1990): Pathogenesis of adult testicular germ cell tumors. A cytogenetic model. Cancer Genet Cytogenet 48:143-167.

12. Oosterhuis JW, Castedo SMMJ, de Jong B, Cornelisse CJ, Dam A, Sleijfer DT, Schraffordt Koops H (1989): Ploidy of primary 
germ cell tumors of the testis. Pathogenetic and clinical relevance. Lab Invest 60:14-20.

13. Fosså SD, Nesland JM, Pettersen EO, Åmellem Ø, Wæhre H, Heimdal K (1991): DNA ploidy in primary testicular cancer. Br J Cancer 64:948-952.

14. Fosså SD, Nesland JM, Wæhre H, Åmellem Ø, Pettersen EO (1991): DNA ploidy in the primary tumor from patients with nonseminomatous testicular germ cell tumors clinical stage I. Cancer 67:1874-1877.

15. El-Naggar AK, Ro JY, McLemore D, Ayala AG, Batsakis JG (1992): DNA ploidy in testicular germ cell neoplasms. Histogenetic and clinical implications. Am J Surg Pathol 16:611618.

16. Oosterhuis JW, de Jong B, Cornelisse CJ, Molenaar IM, Meiring A, Idenburg V, Schraffordt Koops H, Sleijfer DT (1986): Karyotyping and DNA flow cytometry of mature residual teratoma after intensive chemotherapy of disseminated nonseminomatous germ cell tumor of the testis: A report of two cases. Cancer Genet Cytogenet 22:149-157.

17. Castedo SMMJ, de Jong B, Oosterhuis JW, Idenburg VJS, Seruca R, Buist J, te Meerman GJ, Schraffordt Koops H, Sleijfer DT (1989): Chromosomal changes in mature residual teratomas following polychemotherapy. Cancer Res 49:672676.

18. Fidler IJ, Hart IR (1982): Biological diversity in metastatic neoplasms: Origins and implications. Science 217:998-1003.

19. Hong WK, Wittes RE, Hajdu ST, Cvitkovic E, Whitmore WF, Golbey RB (1977): The evolution of mature teratoma from malignant testicular tumors. Cancer 40:2987-2992.
20. Mostofi FK (1980): Pathology of germ cell tumors of testis. Cancer 45:1735-1754.

21. Kelly SA, Lampert I, Jantet G, Price PM (1995): Malignant teratoma undifferentiated (MTU) metastasising solely as differentiated teratoma: Implications for the Aetiology of residual differentiated disease following successful chemotherapy. Eur J Cancer 31A:2120-2121.

22. Kerbel RS, Waghorne C, Korczak B, Lagarde A, Breitman ML, (1988): Clonal dominance of primary tumours by metastatic cells: Genetic analysis and biological implications. Cancer Surv 7:597-629.

23. de Graaff WE, Oosterhuis JW, de Jong B, van Echten J, Wiersema-Buist J, Schraffordt Koops H, Sleijfer DT (1992): Cytogenetic analysis of the mature teratoma and the choriocarcinoma component of a testicular mixed nonseminomatous germ cell tumor. Cancer Genet Cytogenet 61:67-73.

24. de Graaff WE, de Jong B, Oosterhuis JW, van Echten J, Wiersema-Buist J, Schraffordt Koops H, Sleijfer DT (1991): Cytogenetic analysis of the mature and immature teratoma components of a metastatic testicular nonseminomatous germ cell tumor. Cancer Genet Cytogenet 57:59-68.

25. Oosterhuis JW, Andrews PW, Knowles BB, Damjanov I (1984): Effects of Cis-platinum on embryonal carcinoma cell lines in vitro. Int J Canc 34:133-139.

26. Murty VVVS, Bosl GJ, Houldsworth J, Meyers M, Mukherjee AB, Reuter V, Chaganti RSK (1994): Allelic loss and somatic differentiation in human male germ cell tumors. Oncogene 9:2245-2251. 